\title{
The Influence of Image and Reputation on the Competitiveness of Political Party
}

\author{
Dedeh Maryani ${ }^{1}$, Marcellia Susan ${ }^{2}$, Ratih Hurriyati ${ }^{3}$ \\ ${ }^{1}$ Institut Pemerintahan Dalam Negeri (IPDN), Jatinangor, Indonesia \\ ${ }^{2}$ Universitas Kristen Maranatha, Bandung, Indonesia \\ ${ }^{3}$ Universitas Pendidikan Indonesia, Bandung, Indonesia \\ Email: dedehmaryani@pps.ipdn.ac.id
}

\begin{abstract}
The objective of this study is to describe the influence of image and reputation on the competitiveness of a political party. This study uses a quantitative approach with explanatory survey method design, the entire community of West Java Province who has suffrage on the election is the population by taking 400 respondents for the samples, while the random multistage cluster is used as the sampling. Data analysis used in this study is descriptive and verification analyzes, while Partial Least Square (PLS) is used for the hypothesis test. The result shows that there is a significant positive influence of the independent variable of the image of a political party (X1) and variable of the reputation of a political party (X2) on the dependent variable, the competitiveness of political party $(\mathrm{Y})$. We recommend that the image of a political party must be built continuously in order to build a high long-term reputation of the political party, and eventually, it will make the high competitiveness of the political party. It can be done through various programs for the community that could make public trust in political parties increase, for example, the policies made by the government altogether with the legislature must be in favor of the interests of the community. The limitation of this study is the marketing of politics. This is an earlier analysis result.
\end{abstract}

Keyword: Image, Reputation, The Competitiveness of Political Party

\section{A. INTRODUCTION}

One of the factors determining the success of a political party in winning a general election is the marketing of politics or campaigns (Tsianti, 2005). It adopts the concept of service marketing in the private sector that some areas attracting the marketing of politics literature relate to the application of marketing concepts, characteristic process, and marketing structure as well. It is emphasized by the results of Scammell's research (1999) explaining that successful marketing in many service sectors is related to the strategies treating sales as "exchange of relationships", which is trust is exchanged for the implementation of promises. Furthermore, it must be stated, that in the political sector: reputation, image, and leadership evaluation are important factors for its customers or voters. According to Smith \& Hirst (2001), in the last decade, marketing of politics was conducted in the form of activities such as image formation, issue tracking, voter targeting, electoral timings, and assistance in policy formulation.

Recently, related to the image and the reputation of a political party, public trust in almost all countries in the world toward political parties is relatively low or even 
decreased. It is stated by Dalton and Weldon's survey (2005). As in other countries, public trust in a political party in Indonesia is also considered to decrease. It is shown by the increasing abstentions in general elections, both legislative members and the President and Vice President, especially in the year of 2001-2009 (Litbang Kompas, 2009). It needs to get the attention of all political parties to be able to rebuild public trust in the party through improving its image and reputation to enhance the competitiveness of the party.

\section{B. LITERATURE REVIEW}

\section{Marketing of Politics}

According to Scammell (1999: 719), marketing of politics can be seen as something that democratic parties and candidates do in order to be elected, and this is very different from the initial form of selling skills in politics". It is reinforced by O'Cass (1996), that the marketing of politics encourages and enables political parties and voters to be part of a constructive dialogue. Furthermore, Butler and Collins (1994: 19) state that the marketing of politics is marketing ideas and opinions related to public issues, politics, or certain candidates. Along with the opinion of Lees-Marshment (2001), the marketing of politics is about how political organizations adapt business marketing concepts and techniques to help them achieve their goals. Gronroos (1990), Henneberg (1996) quoted by O'Shaughnessy (2001), stated that marketing of politics seeks to establish, maintain and improve long-term relationships with the voters in order to take the benefit of the society and the political parties with the expectation that the goal of the individual political actors and the organizations involved will be fulfilled. This can be done by mutual exchange and fulfillment of promises.

Furthermore, Scammell (1999) argues that reputation, image, and evaluation of leadership are important factors in politics and the service sector. It can be concluded that the focus of marketing of politics leads to managerial issues as the results of research by Kotler (1981), O'Cass (1996), Butler \& Coolins (1994), and Lock \& Harris (1996), some areas attracting the marketing of politics literature relate to the application of marketing concepts, the characteristics process, as well as the marketing structure. Furthermore, it can be said that the marketing of politics shows an interest in consumer research that has a relationship concerning voters as consumers in the business world (Newman, 1985; Shama, 1973).

\section{The Relation of Image and The Competitiveness of Political Party}

Firmanzah (2008) states that a political image as a positioning strategy is one of the deciding sources of victory for some political parties in competition with other political parties. In this case, positioning is a strategy trying to place a party ideology among the ideologies that exist in the minds of the community, so that they will be able to easily identify a political party through an image that is embedded in their belief and 
cognitive systems. Furthermore, it refers to the business sector resulting from Jin-Woo Park, Rodger Robertson and Cheng-Lung Wu's research (2005) which research the influence of the image of the Australian Airlines on the behavior of passengers to attract them to use the airline again and the result shows that it has a positive and significant influence. It means the image of the company influences the competitiveness of the company.

\section{The Relation of Reputation and The Competitiveness of Political Party}

The corporate reputation has an indirect impact on competitive advantage through perceived value and perceived quality of the service. In other words, the firms should communicate their favorable corporate reputation attractively to the market so that the customers' perception level towards their products and service would arise (Awang, 2007). It shows that the reputation of a company has a direct impact on competitive advantage through value and service quality. It means that companies must communicate concerning their reputation effectively to the market so that the level of customer perception of their products and services will be built.

Zhang \& Schwaiger (2009), argue that a model of building a reputation commonly applied to multinational companies in America to enhance competitiveness shows a significant influence on the competitiveness of companies in China. Based on the findings, it can be concluded that the reputation of a company or an organization including a political party will influence the competitiveness of a company, an organization, or a political party.

\section{The Relation of Image and The Reputation of Political Party}

Shamma (2012) citing the opinion of Fombrun (1996), and Doorley and Garcia (2007), describes the relation of the image and reputation of a company in the following equation: Reputation $=f$ (Image + Identity) or reputation as: Reputation $=$ Sum of Images $=($ Performance + Behavior $)+$ Communication .

\section{METHOD}

This study is designed by using an explanatory survey method, a survey trying to connect variables and to test them (Rusidi, 1989). Singarimbun \& Effendi (2005) stated that survey research is research taking samples from a population and uses a questionnaire as a primary data collection tool to research analysis individually. Singarimbun \& Effendi (2005) also argue that the survey method is an explanation if the writer explains the causal relationship between variables through hypothesis testing. The individual population is the entire community in the five selected districts or cities that have already suffrage in the general election which is as much as 7,916,780 people. The number of Individual samples is determined according to the Slovin formula, 400 respondents, The sampling used is multi-stage sampling, stratified random sampling. 
The questionnaire was distributed to 400 respondents who were selected to be the research samples, they are those who already had suffrage in general elections in the selected districts or cities in West Java Province. Interviews were conducted with all managers or representatives of political parties at the Regional Leadership Council (DPW and DPD) of West Java Province. Review documents related to the issues being discussed in this study is data supporting the image, reputation, and competitiveness of political parties. Square (PLS). Partial Least Square (PLS) program is used as a descriptive and verification analyzes through a hypothesis test.

D. RESULT AND DISCUSSION

\section{Descriptive Analysis Result}

Table 1 Category of The Image of Political Party in West Java Province

\begin{tabular}{|c|l|c|c|c|}
\hline No & Dimension/Indicator & $\begin{array}{c}\text { Number of } \\
\text { Question Items }\end{array}$ & F x B Value & Category \\
\hline 1 & The Identity of Party & 3 & 4589 & Good Enough \\
\hline 2 & $\begin{array}{l}\text { The impression of } \\
\text { Parties in public } \\
\text { opinion }\end{array}$ & 2 & 3076 & Good Enough \\
\hline 3 & $\begin{array}{l}\text { Public trust level to } \\
\text { the political parties }\end{array}$ & 2 & 3041 & Good Enough \\
\hline 4 & $\begin{array}{l}\text { The Competence of } \\
\text { the Party }\end{array}$ & 3177 & Good Enough \\
\hline \multicolumn{3}{|c|}{ Value Average of F x B } & $\mathbf{1 5 4 3}$ & Good Enough \\
\hline
\end{tabular}

Source: Data Processing Result, 2020

Table 2 Category of The Reputation of The Political Party in West Java Province

\begin{tabular}{|c|l|c|c|c|}
\hline No & Dimension/Indicator & $\begin{array}{c}\text { Number of } \\
\text { Question Item }\end{array}$ & F x B Value & Category \\
\hline 1 & $\begin{array}{l}\text { Has its peculiarities, for } \\
\text { example, Party's } \\
\text { Ideology }\end{array}$ & 2 & 2799 & Good Enough \\
\hline 2 & $\begin{array}{l}\text { Positive Cultural Values } \\
\text { Developing in the Party }\end{array}$ & 2 & 3105 & Good Enough \\
\hline 3 & $\begin{array}{l}\text { The Consistency of } \\
\text { Party }\end{array}$ & 3 & 4764 & Good Enough \\
\hline 4 & $\begin{array}{l}\text { Transparency of Party } \\
\text { in Managing Party }\end{array}$ & 3 & 4648 & Good Enough \\
\hline \multicolumn{3}{|c|}{ Value Average of F x B } & $\mathbf{1 5 3 2}$ & Good Enough \\
\hline
\end{tabular}

Source: Data Processing Result, 2020 
Table 3 Category of the Competitiveness of the Political Party in West Java Province

\begin{tabular}{|l|l|c|c|c|}
\hline No & Dimension/Indicator & $\begin{array}{c}\text { Number of } \\
\text { Question } \\
\text { Item }\end{array}$ & F x B Value & Category \\
\hline 1 & Arena & 2 & 3125 & Good Enough \\
\hline 2 & Accesss & 2 & 3112 & Good Enough \\
\hline 3 & Advantage & 3 & 4650 & Good Enough \\
\hline 4 & Activities & 3 & 4765 & Good Enough \\
\hline \multicolumn{2}{|r|}{ Average Value of F x B } & $\mathbf{1 5 6 5}$ & Good Enough \\
\hline
\end{tabular}

Source: Data Processing Result, 2020

\section{Verification Analysis Result and Hypothesis Test}

Conversion of path diagram into equalization using Ross $(\mathrm{R})$ program described on the figure below:

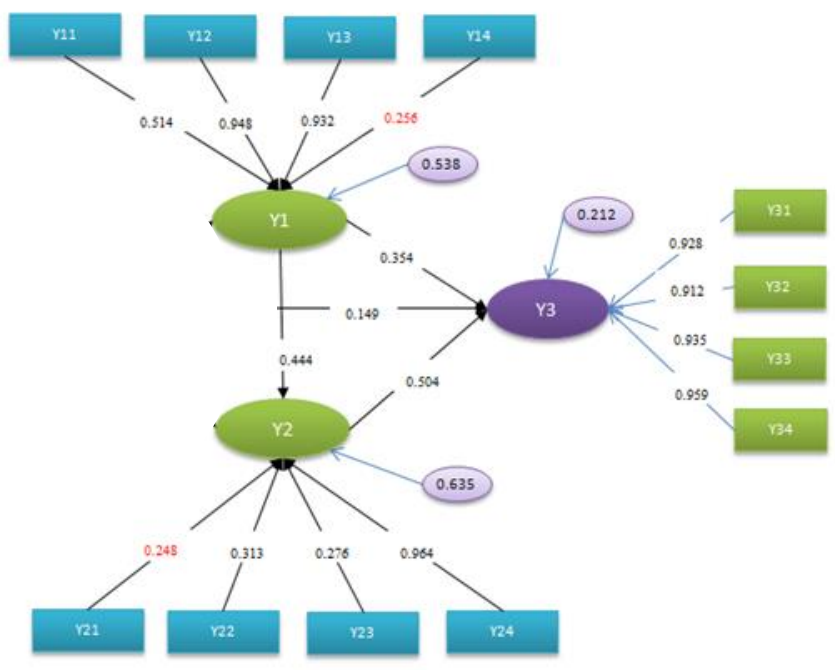

The examination of the path coefficient in the structural model is described in the Figure above and in the Table below. It was conducted to examine empirically the form of relationships based on the theoretical framework of the causal model that has been specified in the early steps of the study.

Table 4 Coefficient Path for Structural Model

\begin{tabular}{|c|r|r|r|r|}
\hline $\begin{array}{c}\text { Coefficien } \\
\mathbf{t} \text { for }\end{array}$ & Original & \multicolumn{1}{|c|}{$\begin{array}{c}\text { Error } \\
\text { Standard }\end{array}$} & \multicolumn{2}{|c|}{$\begin{array}{c}\text { The Magnitude of the } \\
\text { coefficient, Perc 0.05, Perc 0.95 }\end{array}$} \\
\hline $\mathrm{X} 1->\mathrm{X} 2$ & $0.444^{*}$ & 0.457 & 0.052 & 0.379 \\
\hline $\mathrm{X} 1->\mathrm{Y}$ & $0.354^{*}$ & 0.355 & 0.046 & 0.281 \\
\hline $\mathrm{X} 2->\mathrm{Y} 3$ & $0.504^{*}$ & 0.500 & 0.042 & 0.430 \\
\hline
\end{tabular}

Source: Data Processing Result, 2020

Note*) $5 \%$ alpha significant coefficient 
It can be seen on the table that the magnitude of the highest path coefficients as outlined in column 5 and the lowest ones in column 4 , do not exceed the number of 0 . It means all the magnitudes of the coefficients are significant.

The complete direct and indirect influences of endogenous and exogenous latent variables can be seen in the table below.

Table 5 The Direct and Indirect Influences among Latent Variables

\begin{tabular}{|c|c|r|r|r|}
\hline No & Path & $\begin{array}{c}\text { Direct } \\
\text { Influence }\end{array}$ & $\begin{array}{c}\text { Indirect } \\
\text { Influence }\end{array}$ & Total Influence \\
\hline 1 & $\mathrm{X} 1->\mathrm{X} 2$ & 0.444 & 0.000 & 0.444 \\
\hline 2 & $\mathrm{X} 1->\mathrm{Y}$ & 0.354 & 0.224 & 0.579 \\
\hline 3 & $\mathrm{X} 2->\mathrm{Y} 3$ & 0.504 & 0.000 & 0.504 \\
\hline
\end{tabular}

Source: Result of Data Processing, 2020

According to the results of data processing with PLS (Partial Least Square) using $\mathrm{R}$ (Ross) software, the influence of the image of the political parties on the reputation of the political parties, the influence of the image of the political parties on the competitiveness of the political parties and the influence of the reputation of the political parties to the competitiveness of the political parties are as follow:

The results of the study show that the total influence of the image of political parties (X1) on the reputation of political parties (X2) in Indonesia, especially those that occurred in West Java Province is 0.444, it is significant (the degree of error in the tolerable limit (0.05) is 0.052 ). It can be concluded that the research hypothesis four (H1) which states that there is an influence of the image of a political party on the reputation of a political party can be accepted.

The total influence of the image of political parties (X1) on the competitiveness of political parties (Y) through improving the reputation of political parties, especially according to the voters in West Java Province is 0.579 and it is significant (the degree of error in the tolerable limit (below 0 ) is 05 , which is equal to 0.046 ). It can be concluded that research hypothesis five $(\mathrm{H} 2)$ which states that there is an influence of the image of a political party on the competitiveness of political party can be accepted.

The total influence of the reputation of a political party (X2) on the competitiveness of political party $(\mathrm{Y})$ in Indonesia, especially in West Java Province is 0.504 , and it is significant (the degree of error in the tolerable limit (below 0.05) is 0.042 . It is concluded that the research hypothesis six $(\mathrm{H} 3)$ which states that there is an influence of the reputation of political parties on the competitiveness of political parties can be accepted.

The new model developed from the previous concepts put forward by the marketing of politics experts found that the influence of the image and reputation altogether is greater than the image or reputation alone on the competitiveness of 
political parties. It is shown by the influence of $\mathrm{X} 1$ on $\mathrm{Y}$ is 0,44 and the influence of $\mathrm{X} 2$ on $\mathrm{Y}$ is 0,504 while the image and reputation altogether are 0,579

\section{E. CONCLUSION}

The description of the image of the parties which includes the identity of the party, the impression of the party for the people, public trust, and the competence of the party is good enough. The description of the reputation of the party which includes the characteristic of a party, the developing cultural values, the consistency and transparency of party is good enough; The description of competitiveness includes public services, the number of the party participants, diversity of the party channels, the communication of the parties with the community, the strategies of the parties in dealing with the community and competitors and in determining targets and scope of activities can be categorized good enough; The better the image of the parties, the better the reputation of the parties; The better the image of the parties, the higher the competitiveness of the parties; The better the reputation of the parties, the higher the competitiveness of the parties. In this study, it is found a new model that the influence of the image and reputation altogether is greater than the image or reputation alone on the competitiveness of political parties. It is shown by the influence of $\mathrm{X} 1$ on $\mathrm{Y}$ is 0,44 and the influence of $\mathrm{X} 2$ on $\mathrm{Y}$ is 0,504 while the image and reputation altogether is 0,579

\section{REFERENCES}

1. Alie, M. (2012). Pemasaran Politik di Era Multi Partai. Jakarta: Expose.

2. Baines, P. R., Harris, P., \& Lewis, B. R. (2002). The Political Marketing Planning Process: Improving Image and Message in Strategic Target Areas. Marketing Intelligence \& Planning, 20(1).

3. Budiardjo, M. (2008). Dasar-Dasar Ilmu Politik. Jakarta: Gramedia Pustaka Utama.

4. Butler, P., \& Coolins, N. (1996). Strategic Analysis in Political Markets. European Journal of Marketing, 30(10).

5. Dalton, R. J., \& Weldon, S. A. (2005). Public images of political parties: A necessary evil?. West European Politics, 28(5), 931-951.

6. Harris, P., Lock, A., French, A., \& Smith, G. (2010). Measuring political brand equity: a consumer oriented approach. European Journal of Marketing, 44(34).

7. Grönroos, C. (1997). Keynote paper From marketing mix to relationship marketingtowards a paradigm shift in marketing. Management decision, 32(2), 4-20.

8. Henneberg, S. C. (2006). Strategic postures of political marketing: an exploratory operationalization. Journal of Public Affairs: An International Journal, 6(1), 15-30.

9. Kalandrakis, T. (2009). A reputational theory of two-party competition. Quarterly Journal of Political Science, 4(4), 343-378. 
10. Lees-Marshment, J. (2006). Political marketing theory and practice: a reply to Ormrod's critique of the Lees-Marshment market-oriented party model. Politics, 26(2), 119-125.

11. Lees-Marshment, J. (2001). Political marketing and British political parties: The party's just begun. Manchester University Press.

12. Lock, A., \& Harris, P. (1996). Political Marketing- La difference. European Journal of Marketing, 30(10).

13. Morgan, G. (1996). Images of Organization. USA: Sage Publication.

14. Mulligan \& Tsui. (2005). Political Competitiveness, Department of Economics. USA: University of Chicago and Clemson University.

15. Newman, B. I. (2001). An Assessment of The 2000, US Presidential Election: A Set of Political Marketing Guidelines. Journal of Public Affairs, 1(3)

16. Newman, B. I. (2002). The Merging of Public Relations and Political Marketing, Journal of Political Marketing, 1(2).

17. Neuman, L. (2003). Social Research Methods: Qualitative and Quantitative Approaches. Boston: Allyn and Bacon.

18. Niffeneger, P. B. (1989). Strategies for Success from the Political Marketers. The Journal of Consumer Marketing, 6(1)

19. O'Cass, A. (1996). Political Marketing and the marketing Concept. European Journal of Marketing, 30(10).

20. O'Shaughnessy, N. J. (2002). Towardan Ethical Framework for Political Marketing. Psychology and Marketing, 19(2.

21. Schwaiger, M. (2004). Component and Parameters of Corporate Reputation, An Empirical Study. Schmalembach Business Review, 56.

22. Smith, G., \& Hirst, A. (2001). Strategic Political Segmentations. European Journal of Marketing, 35(10).

23. Yang, H. O., \& Fu, H. W. (2007). Creating and Sustaining Competitive Advantages of Hospitality Industry. Journal of American Academy of Business, Cambridge, 12(1). 